Advances in Social Science, Education and Humanities Research, volume 128

3rd International Conference on Education and Training (ICET 2017)

\title{
Measurement Model of Student Well-Being
}

\author{
Durrotunnisa \\ Department of Guidance and Counseling, Tadulako University, Indonesia \\ durrotunnisafkip@gmail.com
}

\begin{abstract}
The purpose of this study was to identify the model of student well-being measurement, school climate and parenting styles. Student well being is measured by the dimensions of positive affect interpersonal and intrapersonal positive affect. School climate is measured by students' perceptions of the physical environment, teachers, and fellow students. Parenting styles are measured by warmth and acceptance, parental control, and autonomy psychological granting. The number of respondents is 118 students of class VIII Junior High School in Malang, consisting of 4 schools. The analysis used is the analysis of Structural Equation Modeling (SEM) version 20. The results show that the null hypothesis in the three models of student well-being measurement, school climate, and parenting styles are accepted, meaning that there is a suitability between the proposed model and the empirical evidence in the field.
\end{abstract}

Keywords: measurement model, structural equation modeling, and student well-being

\section{INTRODUCTION}

Students' success in behaving and positive thinking is colored by the learning outcomes received in their social environment. The main social environment is family and school. Spratt, Schucksmith, and Watson as quoted Micholas (2014) state that schools play a significant role in promoting student welfare, positive student behavior, and positive relationships with students.

The author is interested in researching topics related to student well-being, because some findings in Indonesia, especially with a similar theme, not much published. Perspectives in individual contexts (Micholas, 2014) states that student well-being represents how students respond to school demands on the one hand and how schools can accommodate students' needs and expectations optimally. The research results Currie et. al. (2004) indicates that among several factors that can affect the welfare of students such as joy in schools, academic achievement, peer support, and school pressure. These findings indicate that there are students who love school and there are students who feel pressured by school.

Preliminary studies in Malang pointed to some findings of the gap between students and school life that were not considered comfortable, such as the pressure and heavy duty of teachers (Kompas, 25 February 2013), and because of the dirty and dusty school physical environment (Prasetyo, 2008). The condition is also in line with the findings of Awartani et. al. (2008) indicating that $70 \%$ of students feel uncomfortable when at school, and only $30 \%$ of students feel comfortable in school.

In addition to schools, families also play a role in contributing to the welfare of students. Specifically in Indonesia, past studies have found that parents and families contribute to the formation of well-being students (Rufaedah, 2012 and Nadiva, 2013). Existing research has not linked the two closest environmental factors of the student to the study, parenting parenting as the real form of laying the foundation of the wellbeing, and the school climate as the second living environment for students. This study aims to identify the measurement model in students of SMPN Malang, Indonesia between student well-being, school climate, and parenting. Grand Theory used is positive psychology. Positive psychology is the science of wellbeing: a truth-seeking effort conducted by researching human development and life satisfaction (Hooper, 2012). Positive psychology emphasizes good character to seek positive growth (Sheldon et. al., 2000).

Student well-being (SWB) or student welfare according to the Encyclopedia of Quality of Life and Well-Being Research is the degree to which students feel good in the school environment (De Fraine, Van Landeghem, Van Damme, \& Onghena, in Micholas, 2014). Student well-being in this article is interpreted as the emotional experience of students dominated by positive affects on themselves as well as on others as measured by positive affect interindividual and intraldividual positive affect. The measuring tool used is the student well-being scale developed by the researcher by referring to the positive psychology theory of the specific context.

The National School Climate Council as quoted Thapa, et al. (2014) defines school climate as patterns based on experiences of school life and reflects norms, goals, values, interpersonal relationships, PBM practices, and organizational structures (Cohen, in Micholas, 2014). The study by Ruus et. al. (2007) indicates that climate parameters in Micholas, 2014). The study by Ruus et. al. (2007) shows that school climate parameters are influenced by the value system and attitudes of teachers received by students, the psychological condition of students and their psychological well-being, and academic success. Furthermore, Dewitt and Slade (2014) argue that the school climate involves a proactive approach to the entire school infrastructure and everything related to it.

The school climate in this study is defined as a pattern of psychological experiences of school-related students as measured by indicators of safety and academic support from teachers, fellow students, and school environments. The measuring tool used is a school climate scale developed by researchers. High scores on school climate scores indicate a positive school climate, and low school climate scores indicate a negative school climate. There are three dimensions of parenting initiated parental warm \& acceptance, parental control \& strictness, and psychological autonomy granting and psychological autonomy 
(Sternberg in Krause \& Dailey, 2009; Suldo \& Huebner, 2004).

The warmth of parents and their acceptance of the child is identified through responsive, loving, and involve parentage of the child (Baumrind, 2005). Sternberg and Silk as quoted Bornstein (2002) said parental control of the child is done by controlling the activities of the child, and controlling the behavior according to the standards and limitations of parents (Krause \& Dailey, 2009). The giving of psychological autonomy is done by take and give between parent and child. These three dimensions are outlined in the scale of research designed by researchers to be adapted to the Indonesian context.

\section{METHODS}

Research was conducted in 4 SMPN in Malang city. The number of respondents is 118 students of class VIII, taken by random cluster sampling. Each student fills the scale of the study consisting of a student well-being scale, a school climate scale, and parenting scales. Data analysis using SEM AMOS version 20. According to research objectives, Byrne (2010) states that the measurement model will measure the relationship between observe and unobserve variables, by measuring the relationship between scores on measurement instruments (observe indicator, which in this study indicator means items).

\section{RESULTS AND DISCUSSION}

Student well-being constructs tested are positive affect Interindividual and intrinsdividual positive affect dimensions. The result of confirmatory analysis shows that all items have value loading $>0.4$, but for elektabilitas reason one indicator enough represented one item (Frydenberg \& Lewis, 2009). After tested, the value of GFI $=0.961>0.90$, which means the model is good, Chi square 14.486 value with $\mathrm{p}=0.106>0,05$, which means there is no difference between the measurement model proposed with the empirical model. All items representing the indicator or dimension also have a loading value $>0.4$, so the requirement of validity or unidimensionality has been met.

Construct the school climate, in each construct (physical environment, teacher, fellow students) there are some aborted indicators and some are stated valid with the consideration of minimum factor loading and representation in an indicator. The value of chi square decreased to 89.735 with $\mathrm{p}=0.66>0.05$ after 2 measurement model test, which means no difference between the measurement model and the empirical model. GFI value $=0.912>0.90$, which means the model is declared good, and all items representing indicator or dimension also have value loading $>0.4$, so the requirement of validity or unidimensionality has been fulfilled. The 3 dimensions proposed in the research are accepted with the reliability of Alpha Cronbach of 0.748 . Reliability is an indicator of the validity of convergent (Hair, 2014). Alpha Cronbach reliability value is further compared with composite reliability. Construct Reliability (CR) is often used to connect with the SEM model. The CR calculation earns a value of 0.63 . As per the agreed rules for a good reliability estimate is 0.70 , and reliability between 0.6 to 0.7 is accepted when some indicators in the construct validity of the model are stated well (Hair, 2014).

Construct parenting styles are 3: Strictness, Parental control and autonomy psychological granting. After finding two correlations between error term, chi square value decreased to 30.827 with $p$ value $=0.127$ $>0.05$, which means there is no difference between the measurement model proposed by empirical model. GFI value $=0.943>0.90$, which means the model is declared fit.

The measurement model is significant for the three constructs tested. This means that the measuring instruments used in accordance with the condition of students in SMPN Malang, East Java, Indonesia. Reliability and validity of the instrument can be accounted for statistically. The standard statistical technique for testing measurement models is exploratory factor analysis (EFA). But one of the weaknesses of EFA is not being able to measure the direct relationship between indicators and factors, so Confirmatory Factor Analysis (CFA) is a solution capable of accommodating the need for SEM analysis (Kline, 2005).

The measurement model is used to identify constructs and factors that have been hypothesized by the researcher. The school climate constructs in this study were identified by 3 factors, namely the physical environment, teachers, and fellow students. These findings at least complement the previous discourse which suggests that the dimensions of school climate are safety, relationship, instructional and learning, and institutional environtment (Cohen, 2009). Another school climate domain was initiated by Zullig et al. (2010) covering school security climate, school academic climate, school social climate, and school ownership climate. Domains and previous dimensions are somewhat difficult to translate into observable research indicators, so the researcher considers that the three dimensions proposed in this study are enough to provide an alternative to the Indonesian school climate dimension.

\section{CONCLUSION}

The measurement model on the three constructs of student well-being, school climate and parenting styles is considered fit, since there is no difference between the measurement model proposed and the empirical model.

\section{REFERENCES}

[1] Awartani, M., Whitman, C. V., \& Gordon, J. 2008. Developing Instruments to Capture Young People's Perceptions of how School as a Learning Environment Affects their Well-Being. European Journal of Education,43(1), 51-70.

[2] Baumrind, D. 2005. Patterns of Parental Authority and Adolescent Autonomy - New Directions for Child and Adolescent Development, No. 108, 61-69. D Baumrind - Directions for Child and Adolescent Development. New York: Wiley Library. 
[3] Bornstein, M. H. 2002. Handbook of Parenting Vol. 1 Children and Parenting. London: Lawrence Erlbaum Associates, Publishers.

[4] Byrne, B. M. 2010. Structural Equation Modeling with AMOS Basic Concepts, Applications \& Programming. New York: Routledge Taylor \& Francis Group.

[5] Cohen, J., \& Hamilton, R. O. 2009. Caring for the Individual Student and theCommunity of Learners Interlocking Relationships and Comprehensive School Climate Improvement. Schools: Studies in Education, 6(1), 104-116.

[6] Currie, C., Roberts, C., Morgan, A., Smith, R., Settertobulte, W., Samdal, O., \& Rasmussen, V.B. 2004. Young People's Health in Context Health Behaviour in School-aged Children (HBSC) Study International Report from The 2001/2002 Survey Health Policy for Children and Adolescents, Denmark: WHO.

[7] Dewitt, P. \& Slade, S. 2014. School Climate Change: How Do I Bbuild a Positive Environment for Learning? Alexandria: ASCD.

[8] Frydenberg, E., \& Lewis, R. 2009. Relations Among Well-Being, Avoidant Coping, and Active Coping in A Large Sample of Australian Adolescents. Psychological Reports, 104, 745-758.

[9] Hooper, J. 2012. What Children Need to Be Happy, Confident and Successful step by Step Positive Psychology to Help Children Flourish. London: Jessica Kingsley Publishers.

[10] Kline, R.B. 2005. Principles and Practices of Structural Equation Modeling. London: The Guilford Press.

[11] Kompas. 2013. Guru-guru SMPN 16 Malang Mengajar Semaunya. Retrieved December 1, 2016, from http://www.kompasiana.com/saesaetu/guru-guru-smpn16-malang-mengajarsemaunya 552982746ea83458548b45ec.

[12] Krause, P. H., \& Daily, T. M. 2009. Handbook of Parenting Styles, Stresses, and Strategies. New York: Nova Sciences Publisher, Inc.

[13] Micholas, A.C. 2014. Encyclopedia of Quality of Life and Well-Being Research. New York: Springer Science.

[14] Nadiva, A. 2013. Subyektive Well-Being pada Siswa Akselerasi. Calyptra: Jurnal Ilmiah Mahasiswa Universitas Surabaya, 2(1).

[15] Prasetyo, Y. B. 2008. Pengembangan Ipteks Evaluasi Kesejahteraan Sekolah dengan Pendekatan Model Sekolah Sejahtera di SMP 24 Malang. Research Report. Malang: University of Muhammadiyah Malang.

[16] Rufaedah, A. 2012. Hubungan antara Self-Construal dan Subjective Well-Being pada Etnis Jawa. Thesis. Depok: Indonesia University.

[17] Ruus, V. R., Veisson, M., Leino, M., O., L., Pallas, L., Sarv , E. S., \& Veisson, A. 2007. Students' Well-Being, Coping, Academic Success, and School Climate. Social Behavior and Personality, 35(7), 919-936.

[18] Sheldon, K., Frederickson, B., Rathunde, K., Csikszentmihalyi, M., \& Haidt, J. 2000. Positive Psychology Manifesto. Philadelphia: Batam Books.

[19] Suldo, S. M., \& Huebner, E.S. 2004. The Role of Life Satisfaction i The Relationship between Authoritative Parenting Dimensions and Adolescent Problem Behavior. Social Indicatos Research, 66, 165-195.

[20] Thapa, A., Cohen, J., Guffey, S., \& Higgins, D., and Alessandro, A. 2013. Review of School Climate Research. Review of Educational Research, 83(3), 357385 .
[21] Zullig, K. J., Koopman, T. M., Patton, J. M., \& Ubbes, V. A. 2010. School Climate: Historical Review, Instrument Development \& School Assesment. Journal of Psychoeducational Assesment, 28 (2), 139-152. Retrieved December 1, 2016, from https:www//researchgate.net/publication/23385309. 